\title{
A Comparative Study to Evaluate the Effect of Vaginal pH on Cervical Ripening with Dinoprostone Gel between Rural and Urban Prime Gravid Patients: An Hospital Based Study
}

\author{
Arun Kumar Chauhan ${ }^{1}$, Divya Chaudhary ${ }^{2}$ \\ ${ }^{1}$ Department of Obstetrics \& Gynaecology, Gargi Hospital \& Fertility Research Center, Bhilwara, Rajasthan, India, ${ }^{2}$ Senior Resident, Department of Obstetrics \& \\ Gynaecology, RNT Medical College, Udaipur, Rajasthan, India.
}

\section{Abstract}

Background: Vaginal $\mathrm{pH}$ change also has a role in preterm delivery which suggests that it has a role in influencing cervical ripening. The aim of this study to evaluated the effect of vaginal $\mathrm{pH}$ on cervical ripening with dinoprostone ( $\mathrm{PGE}_{2}$ ) gel between rural and urban primegravida. Subjects and Methods: This is hospital based comparative study done on 50 pregnant women admitted in labour room for induction of labour and fulfilling inclusion/exclusion criteria at Obstetrics and gynaecology department, RNT Medical college, Udaipur. Group I included patients with vaginal $\mathrm{pH}<4.5$ and Group II included vaginal $\mathrm{pH}>4.5$. A vaginal examination was then performed to determine the Bishop's score. After ruling out all contraindications Dinoprostone gel was applied endocervically. Results: Our study showed that mean age of pregnant women was $25.10 \mathrm{yrs}$ in rural patients and $24.56 \mathrm{yrs}$ in urban patients. The high vaginal $\mathrm{pH}(>4.5) \mathrm{was}$ more in urban pregnant women as compare to rural pregnant women, it was statistically non-significant $(\mathrm{P}=0.1062)$ and low vaginal $\mathrm{pH}(\leq 4.5)$ was more in rural as compare to urban. The augmentation required, time to active labor \& time to induction delivery interval was not statistically significant $(\mathrm{P}=0.4276, \mathrm{P}=0.2341 \& \mathrm{P}=0.1445$ respectively) in between rural \& urban pregnant women. LSCS was more common in rural as compare to urban pregnant women, but did not statistically significant $(\mathrm{P}=0.1945 \mathrm{NS})$. Conclusion: We concluded that higher vaginal $\mathrm{pH}$ more often responds to a single induction and is more often associated with vaginal deliveries rather than non-progress of labor.

Keywords: Cervical Ripening, Vaginal pH, Labor Induction, Dinoprostone Gel.

Corresponding Author: Dr. Divya Chaudhary, Senior Resident, Department of Obstetrics \& Gynaecology, RNT Medical College, Udaipur, Rajasthan, India.

Received: March 2020

Accepted: March 2020

\section{Introduction}

Induction of labor is still a arguable obstetric procedure. The need to timely delivery has been recognized and practiced for centuries. The safety of the procedure and the possibility to program labor during daytime is an often heard argument in favor of "day light obstetrics". Also the possibility to prevent intrauterine fetal morbidity and mortality of known or unknown cause and the possibility to apply intra partum fetal surveillance and monitoring from the beginning of labor are put forward as arguments in favor of induction of labor. Thus to initiate the artificial means for initiation of labor we need to understand the parturition cascade with the biopHysio-chemical changes to evolve and establish normal labor and thus realize the impact of induction of labor on achieving it.

The history of labor induction dates back to Hippocrates' original descriptions of mammary stimulation and mechanical dilation of the cervical canal. In 1968, Karim and colleagues were the first to report the use of prostaglandins for labor induction. ${ }^{[1]}$ Since then, the use of prostaglandins, in different varieties and forms of administration, has become a common method of labor induction. More recently, the synthetic prostaglandin analogue misoprostol has gained acceptance as an effective and safe method of labor induction. ${ }^{[2]}$

Cervical Ripening is a series of complex biochemical changes in the cervix which is mediated by the hormones. The cervix contains relatively few smooth muscle cells and derives its rigidity from collagen bundles surrounded by proteoglycans. In pregnancy nearing term, there are various factors that induce certain changes in the cervix leading to cervical ripening. There are agents that can artificially induce these changes if it has not occurred. It is difficult to separate methods of cervical ripening and labor induction. In general vagina maintains a $\mathrm{pH}$ between $3.8-4.8$, which is influenced by frequency of coitus, presence of cervical mucus and the amount of vaginal transudate. The lactic acid produced from glycogen by lactobacillus present in vagina plays an important role in maintaining acidic $\mathrm{pH}$ environment. The vaginal $\mathrm{pH}$ in pregnancy is known to be acidic and not much is known about the variations in vaginal $\mathrm{pH}$ throughout pregnancy. There are studies that mention that $\mathrm{pH}$ may change the degree of ionization of a 
drug and affect the absorption of the drug resulting in variable clinical responses. Vaginal $\mathrm{pH}$ change also has a role in preterm delivery which suggests that it has a role in influencing cervical ripening. The aim of this study to evaluated the effect of vaginal $\mathrm{pH}$ on cervical ripening with dinoprostone $\left(\mathrm{PGE}_{2}\right)$ gel between rural and urban primegravida.

\section{Subjects and Methods}

This is hospital based comparative study done on 50 pregnant women admitted in labour room for induction of labour and fulfilling inclusion/exclusion criteria at Obstetrics and Gynaecology department, RNT Medical college, Udaipur.

\section{Inclusion Criteria}

- No contraindication to vaginal delivery.

- Unfavorable cervix as per modified Bishop's score $\leq$ five.

\section{Exclusion Criteria}

- History of any previous uterine surgery.

- Any past history of drug allergy (prostaglandins) or any contraindication to prostaglandins.

\section{Methods}

Before other examinations were performed, each participant underwent a speculum examination and vaginal $\mathrm{pH}$ value was assessed by using $\mathrm{pH}$ indicator paper (both broad \& narrow spectrum). The indicator paper was placed on the lateral vaginal wall between the two valves of Cusco's speculum until it became wet. Color change of the strip was immediately compared with the manufacturer's colorimetric scale and the finding was recorded. Patients were dived into two groups as Group I \& Group II on basis of their vaginal PH. Group I included patients with vaginal $\mathrm{pH}<4.5$ and Group II included vaginal $\mathrm{pH}>4.5$.

A vaginal examination was then performed to determine the Bishop's score. After ruling out all contraindications Dinoprostone gel was applied endocervically. Following application the patient is instructed to remain recumbent for at least 30 minutes. The patient is then continuously monitored for FHS, fetal moment etc. Reassessment was done after 6 hours for progress and non-progress of labour then statistical analysis was done in form of primary.

\section{Results}

Our study showed that mean age of pregnant women was $25.10 \mathrm{yrs}$ in rural patients and $24.56 \mathrm{yrs}$ in urban patients [Table 1]. The high vaginal $\mathrm{pH}(>4.5)$ was more in urban pregnant women as compare to rural pregnant women, it was statistically non-significant $(\mathrm{P}=0.1062)$ and low vaginal $\mathrm{pH}(\leq 4.5)$ was more in rural as compare to urban [Table 2]. The augmentation required, time to active labor \& time to induction delivery interval was not statistically significant $(\mathrm{P}=0.4276, \mathrm{P}=0.2341 \& \mathrm{P}=0.1445$ respectively) in between rural\& urban pregnant women [Table 3]. LSCS was more common in rural as compare to urban pregnant women, but did not statistically significant ( $\mathrm{P}=0.1945 \mathrm{NS}$ ) [Table 4].

Table 1: Age wise distribution of patients
\begin{tabular}{|l|l|l|l|}
\hline & Rural & Urban & P-value \\
\hline Mean Age & $25.10 \mathrm{yrs}$ & $24.56 \mathrm{yrs}$ & $0.2132 \mathrm{NS}$ \\
\hline SD & 2.523 & 2.415 & \\
\hline Range & $21-32 \mathrm{yrs}$ & $20-30 \mathrm{yrs}$ & \\
\hline
\end{tabular}

Table 2: Distribution of patients according to vaginal $\mathrm{pH}$ in rural and urban pregnant women

\begin{tabular}{|l|l|l|l|}
\hline Vaginal pH & Rural & Urban & P-value \\
\hline$>4.5$ & $14(56 \%)$ & $18(72 \%)$ & \multirow{2}{*}{0.1062} \\
\cline { 1 - 3 }$\leq 4.5$ & $11(44 \%)$ & $7(28 \%)$ & \\
\cline { 1 - 3 } Total & $25(100 \%)$ & $25(100 \%)$ & \\
\cline { 1 - 2 }
\end{tabular}

Table 3: Distribution of cases according to Progress of labor after induction in rural \& urban pregnant women

\begin{tabular}{|l|l|l|l|l|}
\hline \multicolumn{2}{|l|}{ Progress of labor } & Rural & Urban & P-value \\
\hline $\begin{array}{l}\text { Augmentatio } \\
\text { n required }\end{array}$ & $\begin{array}{l}\text { Ye } \\
\text { s }\end{array}$ & $4(16 \%)$ & $2(8 \%)$ & \multirow{2}{*}{6} \\
\cline { 2 - 4 } & No & $21(84 \%)$ & $23(92 \%)$ & \\
\hline \multicolumn{2}{|l|}{ Time to active labor } & \begin{tabular}{l}
$5.002 \pm 3.12$ \\
\multicolumn{2}{|l|}{8}
\end{tabular} & $\begin{array}{l}4.027 \pm 1.01 \\
4\end{array}$ & $0.2341 \mathrm{NS}$ \\
\hline $\begin{array}{l}\text { Induction delivery } \\
\text { interval }\end{array}$ & $7.215 \pm 3.00$ & $6.251 \pm 2.84$ & $0.1445 \mathrm{NS}$ \\
\hline
\end{tabular}

Table 4: Distribution of cases according to mode of delivery in rural \& urban pregnant women

\begin{tabular}{|l|l|l|l|}
\hline $\begin{array}{l}\text { Mode of } \\
\text { Delivery }\end{array}$ & Rural & Urban & \multirow{2}{*}{ P-value } \\
\hline FTNVD & $21(84 \%)$ & $23(92 \%)$ & \multirow{2}{*}{0.1005 NS } \\
\cline { 1 - 2 }$(\mathrm{FD})$ & $2(8 \%)$ & $1(4 \%)$ & \\
\hline LSCS (MSL) & $2(8 \%)$ & $1(4 \%)$ & \\
\hline
\end{tabular}

\section{Discussion}

Our study showed that mean age of pregnant women was $25.10 \mathrm{yrs}$ in rural patients and $24.56 \mathrm{yrs}$ in urban patients. Hindu by religion belonging to upper middle class modified by B.J. Prasad in both rural \& urban group. Also for those living a long distance from the hospital or living in isolated rural areas consideration for induction to avoid living away from home for weeks, awaiting labor or travelling long distances for birthing. Being due around a holiday season some women choose to be induced before festivals or school holidays.

The high vaginal $\mathrm{pH}(>4.5)$ was more in urban pregnant women as compare to rural pregnant women, it was statistically non-significant $(\mathrm{P}=0.1062)$ and low vaginal $\mathrm{pH}$ $(\leq 4.5)$ was more in rural as compare to urban. Onen fi et al (2008),${ }^{[3]}$ reported that the Vaginal $\mathrm{pH}$ has significant effect on cervical ripening but has no effect on delivery outcomes in post-term patients with unfavorable cervices, who undergo cervical priming/ labor induction using sustainedrelease dinoprostone vaginal insert. Another study done by Goswami $\mathrm{J}$ et al (2015), ${ }^{[4]}$ reported that no significant differences were noted between those patients with vaginal $\mathrm{pH} \leq 4.5$ (group 1) compared with those with high $\mathrm{pH}>4.5$ 
(group II) with respect to maternal age, gestational age and gravidity.

A conflict our results by Ramsey PS et al (2002), ${ }^{[5]}$ found no significant differences were noted between women with a high vaginal $\mathrm{pH}(>4.5, \mathrm{n}=16$ women $)$ and women with a low vaginal $\mathrm{pH}$ ( $<$ or $=4.5, \mathrm{n}=16$ women) with respect to maternal age, parity, gestational age, or initial Bishop Score.

The augmentation required, time to active labor \& time to induction delivery interval was not statistically significant $(\mathrm{P}=0.4276, \mathrm{P}=0.2341 \& \mathrm{P}=0.1445$ respectively) in between rural \& urban pregnant women. Vaginal route include accessibility, good blood supply, the ability to bypass firstpass liver metabolism, and permeability to large molecular weight drugs, such as peptides and proteins.

Ramsey PS et al (2002), ${ }^{[5]}$ reported that a significant association was noted between vaginal $\mathrm{pH}$ and time to active labor $(\mathrm{r}=-0.52, \mathrm{P}=.003)$, complete dilation $(\mathrm{r}=$ $0.50, \mathrm{P}=.006)$, and delivery $(\mathrm{r}=-0.44, \mathrm{P}=.01)$; however, $\mathrm{pH}$ was not significantly associated with Bishop score change during the initial 12 hours of cervical ripening. Singh U et al (2011), ${ }^{[6]}$ found no significant difference between the low \& high $\mathrm{pH}$ with respect to time to onset of labour $(p=0.066)$, time to active labour $(p=0.664)$, time to complete cervical dilation $(\mathrm{p}=0.984)$, and time to overall delivery $(\mathrm{p}=0.381)$.

Basirat Z et al (2012), ${ }^{[7]}$ the incidence of Cesarean section was lower in women with high vaginal $\mathrm{pH}$.Goswami $\mathrm{J}$ et al $(2015),{ }^{[4]}$ reported vaginal $\mathrm{pH}$ has significant effect on cervical ripening and delivery outcome.

Caesarian section was more in lower vaginal $\mathrm{pH}$ as compare to higher vaginal $\mathrm{pH}$ and normal vaginal delivery was more in higher vaginal $\mathrm{pH}$ in rural pregnant women in our study. Vaginal $\mathrm{pH}$ has been investigated in several recent studies as a factor that may account for the variability observed clinically with prostaglandin used as labor induction agents. Two in vitro studies by Johnson et al. ${ }^{[8]}$ and MacDonald and Weir, ${ }^{[9]}$ describes an increased $\mathrm{PGE}_{2}$ release in solutions with a higher $\mathrm{pH}$. (6.5 to 7.5) It was also reported in the two in vitro studies that along with the increased release of $\mathrm{PGE}_{2}$, it is also predominantly ionizes at a $\mathrm{pH}$ of $7.5(\mathrm{pKa}$, 4.9), which diminishes the potential of its systemic absorption and there by increases its local action.

\section{Conclusion}

We concluded that higher vaginal $\mathrm{pH}$ more often responds to a single induction and is more often associated with vaginal deliveries rather than non-progress of labor. Hence knowing the vaginal $\mathrm{pH}$ prior to induction could prove to be a useful tool in assessing the labor outcome of a patient undergoing labor induction with PGE2 gel.

\section{References}

1. Karim SM, Trussell RR, Patel RC, Hillier K. Response of Pregnant Human Uterus to Prostaglandin F2 alpha induction of Labor. Br Med J. 1968 Dec; 4(5631):621-3.

2. L. Sanchez-Ramos, A.M. Kaunitz and G.O. Del Valle. Labor Induction with the Prostaglandin E1 Methyl Analogue Misoprostol Versus Oxytocin: A Randomized Trial. Obstetrics Gynecology. 1993: 81 (3):332-6.

3. FiahinÖnen, GülnurÖzakfi<T, BülentYilmaz, TayfunGüngör, ÜmitB $\measuredangle$ Lge, NecdetSüt,LeylaMollamahmutoLu. The Role of Vaginal $\mathrm{pH}$ on Efficacy of Controlled-Release Dinoprostone Vaginal Insert for Cervical Ripening/Labor Induction: A Prospective Double-Blind Study. J Turkish-German Gynecol Assoc. 2008; 9(4): 206-11.

4. Goswami J, Choudhury SS, Deka G. Effect of vaginal $\mathrm{pH}$ in cervical ripening with dinoprostone gel. The New Indian Journal of OBGYN, 2015; 2(1): 32-6.

5. Ramsey PS, Ogburn PL Jr, Harris DY, Heise RH, Ramin KD. Effect of vaginal $\mathrm{pH}$ on efficacy of the dinoprostone gel for cervical ripening/labor induction. Am J Obstet Gynecol. 2002 Oct; 187(4): 843-6.

6. Singh U, Mehrotra S, Gupta HP, Dhakad A, Jain V. A prospective double blind trial investigating impact of vaginal $\mathrm{pH}$ on efficacy of prostaglandin gel for cervical ripening and course of labour. J ObstetGynaecol. 2011;31(3):217-9.

7. Basirat Z, Barat SH, Ghanbarpour A, Golsorkhtabar-Amiri M. Does vaginal $\mathrm{pH}$ affect the efficacy of dinoprostone in cervical ripening/labor duration? Clin Exp Obstet Gynecol. 2012; 39(4): 522-5.

8. Johnson TA, Greer IA, Kelly RW, Calder AA. The effect of $\mathrm{pH}$ on the release of PGE2 from vaginal and endocervical preparations for induction of labour:an in-vitro study. Br J Obstet Gynaecol. 1992; 99 (11): 877-80.

9. MacDonald IA, Weir RF. The effect of $\mathrm{pH}$ on release of PGE2 from vaginal and endocervical preparations for induction of labour.Br $\mathrm{J}$ Obstet Gynaecol. 1993;100 (11):1066-7.

Copyright: (C) the author(s), 2020. It is an open-access article distributed under the terms of the Creative Commons Attribution License (CC BY 4.0), which permits authors to retain ownership of the copyright for their content, and allow anyone to download, reuse, reprint, modify, distribute and/or copy the content as long as the original authors and source are cited.

How to cite this article: Chauhan AK, Chaudhary D. A Comparative Study to Evaluate the Effect of Vaginal pH on Cervical Ripening with Dinoprostone Gel between Rural and Urban Prime Gravid Patients: An Hospital Based Study. Asian J. Med. Res. 2020;9(1):OG01-OG03.

DOI: dx.doi.org/10.47009/ajmr.2020.9.1.OG1

Source of Support: Nil, Conflict of Interest: None declared. 